\title{
The Investigation of Students' Knowledge on a Novel Learning Strategy: What is Interesting about Blended Learning for EFL University Students?
}

\author{
Riska Yuliana ${ }^{1}$, Marwa Marwa $^{2}$, \& Budianto Hamuddin ${ }^{3}$ \\ ${ }_{1,2}$ Universitas Lancang Kuning, Pekanbaru. Indonesia \\ ${ }^{3}$ Universitas Hasanuddin, Makassar. Indonesia \\ budihamuddin@gmail.com
}

\begin{abstract}
Received : 2019-05-03
Revised : 2019-06-27

Accepted : 2020-07-05
\end{abstract}

ARTICLE HISTORY

\section{KEYWORDS}

Learning Strategy Blended Learning EFL Students PBIG FKIP Unilak

\begin{abstract}
This research aimed at exploring students' interest and knowledge in blended learning context at English Education Department in Universitas Lancang Kuning (Unilak). This descriptive quantitative research involved 27 out of 135 students as the samples as they are part of a class that uses blended learning actively through their entire semester. These 27 students were selected by using random sampling technique from fourth, sixth, and eight semesters in regular class. The questionnaire used as the main instrument to collect the data. The data analyzed descriptively in term of mean and standard deviation then interpreted descriptively. The result of the findings revealed that the majority of students' have high level of students' interest and knowledge in blended learning context. It was proved by their mean score, interest students' score 3.71 and the students' knowledge score 3.67. The standard deviation to interest was 6,83 and knowledge was 5.28. This is means that the blended learning which employed during these 2 years in this department seems contributing a high interest and knowledge among the students.
\end{abstract}

\section{Introduction}

Information technology (IT) has changed the learning through communication evolution, expanding audience (teleconferences), interactive textbooks, eBooks, tablet computing devices, extended classroom communities, and the rise of the World Wide Web. Limiting the use of technology only to presentations creates that confusion in relation to its feasibility in improving learning (Bond, Buntins, Bedenlier, Zawacki-Richter, \& Kerres, 2020). We need to think of technology as a tool that enables us to reach resources easily and effectively (Junaidi, Hamuddin, Julita, Rahman, \& Derin, 2020). We can access libraries, hold conferences, watch educational movies, conduct virtual experiments, communicate with experts, record lessons, plan their work, made virtual field trips and many other activities. Some of these activities needed weeks of planning and lots of effort within the traditional learning setting (Medora \& Roy, 2017; Strogilos, Stefanidis, \& Tragoulia, 2016).

Further, 21st century assigns new challenges and duties on the modern era. A method of teaching English has changed drastically with the entry of technology in our lives. Technology can provide facilities that so many choices for teachers that can make their teaching more interesting and adore by students (Nursafira, 2020; Sağin, 2020). This blended learning "new things" including multimedia in teaching English to create the students' interest and knowledge in learn English through blended learning more practical and humanism. This helps students to get involved maximally and learn according to their interests. This idea has been proven by many kinds of research that effectively and is widely accepted for teaching English in a modern world (Putri, Hamuddin, Nursafira, \& Derin, 2020; Yudar, Aditomo, Silalahi, 2020).

Blended learning allows learners to visualize, listen, feel, and interact with the learning material. It moves them from theory into practice. They can gain a deeper understanding of all the abstractions they get through. They can learn according to their pace, which creates the opportunity for more individualized education as their learning is facilitated with many alternative learning media and entertaining learning tools (Kamelia, 2019; Putri, 2019). Good achiever can expand their learning and learn things that are not within the syllabus. However, the slow achievers can repeat and revise notes and get feedback from their teachers to overcome the problems and challenges they face (Bailey et al., 2013; DeMillo et al., 2016). With support from the extending IT made the blended learning strategy become easier to be implemented. For example, a visit to the public library take a whole day within the traditional learning strategy; however, students can virtually access the public library records and reach the books and resources they need while being seated in their classrooms or even their bedrooms (Bath and Bourke, 2010; Black \& Muddiman, 2017; Crane, 2016). 
Based on the introduction, the problems of the research were stated as follows: a) How is the students' interest in learning English through blended learning at English Education Department in Universitas Lancang Kuning? b) How is the students' familiarity using Blended Learning at English Education Department in Universitas Lancang Kuning?

\section{Method}

This survey design as descriptive quantitative study in nature seeks for an answer of the research questions. Survey research is defined as the collection of information from a sample of individuals through their responses to questions (Knoke, Marsden, \& Kalleberg, 2017). The research used random sampling technique. If population is more than 100 person, the sample taken between $10-15 \%$ or $20-25 \%$, but if population is less than 100 person, the sample can be take all of the population (Arikunto, 1996; Story \& Tait, 2019). Based on explanation above, in this research the researcher takes about $20 \%$ of the population, which were about 27 students. The instrument is an online questionnaire.

In the questionnaire consisted of 20 questions. The researcher also used likert scale that consist of five choices; strongly agree, agree, neither, disagree, and strongly disagree. So, the students able to select one of the answer-based on their opinion in blended learning context. Each choice had score to calculate the data from the questionnaire. The questionnaire would be administered to the students to get the data about their interest and knowledge in blended learning context. The online questionnaire on google form is distributed by link-sharing in WhatsApp class groups. Then, the researcher calculated the mean and standard deviation of each variables and each sub indicator of questionnaire.

\section{Results and Discussion}

\subsection{Try Out of the Questionnaire}

The researcher had done try out the questionnaire that consist of 20 questions to the students of English Education Department in Universitas Lancang Kuning on Monday, 1 July 2019. The researcher tried out the questionnaire in order to check the validity and reliability of the test. The researcher collected the data after all 27 students filled the google form on 13 July 2019. the researcher tabulated the score of the students' answers to check the validity and reliability by using SPSS version 23 program. Then, the researcher saw that from 20 questions still 20 questions that have been valid and reliable.

\subsection{Results of the Questionnaire}

The questionnaire was given by the researcher to collect quantitative data. The researcher gave the questionnaire to all students' at English Education Department in Universitas Lancang Kuning on 1-13 July 2019. The questionnaire was given to answer the research question, "How is the students' interest in learning English through blended learning at English Education Department in Universitas Lancang Kuning?”.

The researcher gave 20 questions about interest and knowledge. The number of interest questions was 10 questions to give 27 students at English Education Department in Universitas Lancang Kuning. First, the researcher explained about the procedure to fill the questionnaire to the students. Then, the researcher gave the link to the students to answer the question. The questionnaire consisted of one indicator of interest and have three sub indicators they are; motivation, emotion, and interaction.

After sharing the questionnaire, the researcher tabulated and calculated the score of the questionnaire. The researcher would like to present the data and descriptive statistics from the data. The researcher used mean and standard deviation to calculate the total of students in each scale of the question.

In this research it can be seen the students' interest in learning English through blended learning at English Education Department in Universitas Lancang Kuning. The students' interest in learning English through blended learning at English Education Department in Universitas Lancang Kuning can be categorized into high. Based on data showed that the total of raw score of students was 1203 with the mean was 3.71 and the standard deviation of the students' score was 6.8 .

Table 1. Descriptive Statistic Scores the SubIndicators of Students Interest (Motivation)

\begin{tabular}{|c|c|c|c|c|c|c|}
\hline \multirow{2}{*}{ NO } & \multicolumn{4}{|c|}{ Items } & \multirow{2}{*}{ total } & \multirow{2}{*}{ mean } \\
\hline & 1 & 2 & 3 & 4 & & \\
\hline S1 & 4 & 4 & 3 & 3 & 14 & 3.50 \\
\hline S2 & 4 & 4 & 5 & 5 & 18 & 4.50 \\
\hline S3 & 4 & 5 & 4 & 5 & 18 & 4.50 \\
\hline S4 & 4 & 4 & 5 & 4 & 17 & 4.20 \\
\hline S5 & 5 & 5 & 4 & 4 & 18 & 4.50 \\
\hline S6 & 5 & 5 & 4 & 4 & 18 & 4.50 \\
\hline S7 & 4 & 4 & 4 & 4 & 16 & 4.00 \\
\hline S8 & 4 & 4 & 4 & 4 & 16 & 4.00 \\
\hline S9 & 4 & 4 & 4 & 4 & 16 & 4.00 \\
\hline $\mathrm{S} 10$ & 4 & 4 & 4 & 4 & 16 & 4.00 \\
\hline S11 & 4 & 4 & 4 & 4 & 16 & 4.00 \\
\hline
\end{tabular}




\begin{tabular}{|l|c|c|c|c|c|c|}
\hline S12 & 4 & 4 & 4 & 4 & 16 & 4.00 \\
\hline S13 & 3 & 4 & 5 & 3 & 15 & 3.70 \\
\hline S14 & 5 & 4 & 4 & 4 & 17 & 4.20 \\
\hline S15 & 4 & 5 & 3 & 5 & 17 & 4.20 \\
\hline S16 & 2 & 3 & 3 & 3 & 11 & 2.70 \\
\hline S17 & 5 & 4 & 4 & 5 & 18 & 4.50 \\
\hline S18 & 3 & 3 & 4 & 3 & 13 & 3.20 \\
\hline S19 & 3 & 3 & 2 & 2 & 10 & 2.50 \\
\hline S20 & 4 & 5 & 5 & 5 & 19 & 4.70 \\
\hline S21 & 2 & 2 & 2 & 3 & 9 & 2.20 \\
\hline S22 & 4 & 4 & 3 & 4 & 15 & 3.70 \\
\hline S23 & 4 & 4 & 3 & 4 & 15 & 3.70 \\
\hline S24 & 4 & 4 & 3 & 4 & 15 & 3.70 \\
\hline S25 & 4 & 4 & 4 & 4 & 16 & 4.00 \\
\hline S26 & 3 & 2 & 3 & 3 & 11 & 2.70 \\
\hline S27 & 4 & 4 & 4 & 4 & 16 & 4.00 \\
\hline & \multicolumn{7}{|c|}{ Total } & & & $\mathbf{4 1 6}$ \\
\hline & Mean & & $\mathbf{3 . 8}$ \\
\hline Standar deviasi & & & $\mathbf{2 . 5}$ \\
\hline
\end{tabular}

Based on the table 1, it can be seen the subindicators of interest was motivation in learning English through blended learning at English Education Department in Universitas Lancang Kuning can be categorized into High. Based on table 1 above, the table showed that the total of raw score of students was 416 with the mean was 3.85 and the standard deviation of the students' score was 2.59.

Table 2. Descriptive Statistic Scores the SubIndicators of Students Interest (Emotion)

\begin{tabular}{|c|c|c|c|c|c|c|}
\hline \multirow{2}{*}{ NO } & \multicolumn{4}{|c|}{ Items } & \multirow{2}{*}{ total } & \multirow{2}{*}{ mean } \\
\hline & 1 & 2 & 3 & 4 & & \\
\hline S1 & 2 & 4 & 3 & 3 & 12 & 3.00 \\
\hline S2 & 4 & 4 & 3 & 4 & 15 & 3.75 \\
\hline S3 & 4 & 4 & 4 & 4 & 16 & 4.00 \\
\hline S4 & 2 & 5 & 3 & 5 & 15 & 3.75 \\
\hline S5 & 4 & 4 & 4 & 4 & 16 & 4.00 \\
\hline S6 & 4 & 4 & 4 & 4 & 16 & 4.00 \\
\hline S7 & 4 & 4 & 4 & 4 & 16 & 4.00 \\
\hline S8 & 2 & 4 & 4 & 3 & 13 & 3.25 \\
\hline S9 & 2 & 4 & 2 & 4 & 12 & 3.00 \\
\hline S10 & 4 & 4 & 4 & 4 & 16 & 4.00 \\
\hline S11 & 3 & 4 & 3 & 3 & 13 & 3.25 \\
\hline S12 & 4 & 4 & 4 & 4 & 16 & 4.00 \\
\hline S13 & 2 & 4 & 4 & 3 & 13 & 3.25 \\
\hline S14 & 5 & 4 & 4 & 4 & 17 & 4.25 \\
\hline
\end{tabular}

\begin{tabular}{|c|c|c|c|c|c|c|}
\hline S15 & 4 & 4 & 4 & 4 & 16 & 4.00 \\
\hline S16 & 4 & 3 & 3 & 3 & 13 & 3.25 \\
\hline S17 & 5 & 5 & 5 & 5 & 20 & 5.00 \\
\hline S18 & 4 & 4 & 3 & 3 & 14 & 3.50 \\
\hline S19 & 2 & 3 & 1 & 2 & 8 & 2.00 \\
\hline S20 & 2 & 5 & 5 & 5 & 17 & 4.25 \\
\hline S21 & 3 & 3 & 3 & 4 & 13 & 3.25 \\
\hline S22 & 4 & 5 & 3 & 5 & 17 & 4.25 \\
\hline S23 & 4 & 4 & 3 & 5 & 16 & 4.00 \\
\hline S24 & 3 & 3 & 4 & 2 & 12 & 3.00 \\
\hline S25 & 4 & 4 & 4 & 4 & 16 & 4.00 \\
\hline S26 & 2 & 3 & 3 & 3 & 11 & 2.75 \\
\hline S27 & 4 & 4 & 5 & 4 & 17 & 4.25 \\
\hline \multicolumn{5}{|c|}{ Total } & \multicolumn{2}{|c|}{396} \\
\hline \multicolumn{5}{|c|}{ Mean } & \multicolumn{2}{|c|}{3.66} \\
\hline \multicolumn{5}{|c|}{ Standard Deviation } & \multicolumn{2}{|c|}{2.48} \\
\hline
\end{tabular}

Based on the table 2, it can be seen the subindicators of interest was emotion in learning English through blended learning at English Education Department in Universitas Lancang Kuning can be categorized into High. Further, Based on table 2, the table showed that the total of raw score of students was 396 with the mean was 3.67 and the standard deviation of the students' score was 2.49.

Table 3. Descriptive Statistic Scores the Sub-Indicators of Students Interest (Interaction)

\begin{tabular}{|c|c|c|c|c|c|c|}
\hline \multirow{2}{*}{ NO } & \multicolumn{4}{|c|}{ Item } & \multirow{2}{*}{ Total } & \multirow{2}{*}{ Mean } \\
\hline & 1 & 2 & 3 & 4 & & \\
\hline $\mathrm{S} 1$ & 3 & 3 & 3 & 4 & 13 & 3.25 \\
\hline S2 & 4 & 4 & 5 & 4 & 17 & 4.25 \\
\hline S3 & 4 & 4 & 3 & 4 & 15 & 3.75 \\
\hline S4 & 3 & 3 & 3 & 3 & 12 & 3.00 \\
\hline S5 & 5 & 5 & 5 & 5 & 20 & 5.00 \\
\hline S6 & 4 & 4 & 4 & 4 & 16 & 4.00 \\
\hline S7 & 4 & 4 & 4 & 4 & 16 & 4.00 \\
\hline S8 & 3 & 4 & 4 & 4 & 15 & 3.75 \\
\hline S9 & 3 & 3 & 4 & 2 & 12 & 3.00 \\
\hline S10 & 4 & 4 & 4 & 4 & 16 & 4.00 \\
\hline S11 & 3 & 4 & 3 & 4 & 14 & 3.50 \\
\hline S12 & 3 & 4 & 4 & 4 & 15 & 3.75 \\
\hline S13 & 2 & 5 & 2 & 4 & 13 & 3.25 \\
\hline S14 & 3 & 4 & 4 & 4 & 15 & 3.75 \\
\hline S15 & 3 & 4 & 4 & 4 & 15 & 3.75 \\
\hline S16 & 3 & 3 & 3 & 3 & 12 & 3.00 \\
\hline
\end{tabular}




\begin{tabular}{|l|l|l|l|l|l|l|} 
S17 & 4 & 4 & 4 & 4 & 16 & 4.00 \\
\hline S18 & 2 & 4 & 4 & 4 & 14 & 3.50 \\
\hline S19 & 3 & 3 & 3 & 3 & 12 & 3.00 \\
\hline S20 & 4 & 5 & 5 & 5 & 19 & 4.75 \\
\hline S21 & 2 & 2 & 2 & 2 & 8 & 2.00 \\
\hline S22 & 4 & 3 & 5 & 4 & 16 & 4.00 \\
\hline S23 & 4 & 3 & 5 & 4 & 16 & 4.00 \\
\hline S24 & 2 & 4 & 2 & 4 & 12 & 3.00 \\
\hline S25 & 3 & 4 & 4 & 4 & 15 & 3.75 \\
\hline S26 & 2 & 3 & 3 & 3 & 11 & 2.75 \\
\hline S27 & 3 & 5 & 4 & 4 & 16 & 4.00 \\
\hline \multicolumn{7}{|c|}{ Total } \\
\hline \multicolumn{7}{|c|}{ Mean } \\
\hline
\end{tabular}

Based on the table above, it can be seen the subindicators of interest was interaction in learning English through blended learning at English Education Department in Universitas Lancang Kuning can be categorized into High. Based on table 3 above, the table showed that the total of raw score of students was 391 with the mean was 3.62 and the standard deviation of the students' score was 2.52 .

\subsection{The result of Students' Knowledge Using Blended Learning}

The questionnaire was given by the researcher to collect quantitative data. The researcher gave the questionnaire to all students' at English Education Department in Universitas Lancang Kuning on 10th 13rd july 2019. The questionnaire was given to answer the research question," How is the students' familiarity using blended learning at English Education Department in Universitas Lancang Kuning?" The researcher gave 20 questions about interest and knowledge. The number of knowledge questions was 10 questions to gave 27 students at English Education Department in Universitas Lancang Kuning. First, the researcher explained about the procedure to fill the questionnaire to the students. Then, the researcher gave the link to the students to answer the question. The questionnaire consisted of one indicator of interest and have three sub indicators they are; motivation, emotion, and interaction.

After shared the questionnaire, the researcher tabulated and calculated the score of the questionnaire. The researcher would like to present the data and descriptive statistics from the data. The researcher used percentage formulation to calculated the total of students in each scale of the question and descriptive statistics data there is mean. The description of the scores that had already been analyzed can be seen in the following table:

Table 4. Descriptive Statistics Scores of the Students' Knowledge in Blended Learning

\begin{tabular}{|c|c|c|c|c|c|c|c|c|c|c|}
\hline \multirow{2}{*}{ NO } & \multicolumn{8}{|c|}{ Item } & \multirow{2}{*}{$\mathbf{T}$} & \multirow{2}{*}{ Mean } \\
\hline & 1 & 2 & 3 & 4 & 5 & 6 & 7 & 8 & & \\
\hline $\mathrm{S} 1$ & 4 & 4 & 3 & 4 & 3 & 3 & 3 & 3 & 27 & 3.37 \\
\hline $\mathrm{S} 2$ & 4 & 3 & 4 & 4 & 3 & 4 & 5 & 4 & 31 & 3.87 \\
\hline S3 & 4 & 4 & 3 & 3 & 3 & 5 & 5 & 5 & 32 & 4.00 \\
\hline S4 & 3 & 5 & 4 & 5 & 4 & 4 & 4 & 4 & 33 & 4.12 \\
\hline S5 & 4 & 4 & 5 & 5 & 4 & 5 & 5 & 4 & 36 & 4.50 \\
\hline S6 & 4 & 5 & 5 & 4 & 4 & 4 & 4 & 4 & 34 & 4.25 \\
\hline S7 & 3 & 2 & 2 & 4 & 3 & 4 & 4 & 4 & 26 & 3.25 \\
\hline S8 & 3 & 4 & 4 & 4 & 4 & 4 & 4 & 4 & 31 & 3.87 \\
\hline S9 & 4 & 4 & 4 & 4 & 4 & 4 & 4 & 4 & 32 & 4.00 \\
\hline S10 & 4 & 5 & 4 & 4 & 4 & 4 & 4 & 4 & 33 & 4.12 \\
\hline S11 & 4 & 4 & 3 & 3 & 3 & 3 & 4 & 3 & 27 & 3.37 \\
\hline S12 & 3 & 4 & 3 & 4 & 4 & 4 & 4 & 4 & 30 & 3.75 \\
\hline S13 & 4 & 4 & 4 & 3 & 2 & 2 & 4 & 2 & 25 & 3.12 \\
\hline S14 & 4 & 4 & 4 & 4 & 4 & 4 & 4 & 4 & 32 & 4.00 \\
\hline S15 & 4 & 5 & 4 & 3 & 3 & 3 & 4 & 4 & 30 & 3.75 \\
\hline S16 & 3 & 3 & 3 & 3 & 3 & 3 & 3 & 3 & 24 & 3.00 \\
\hline S17 & 5 & 4 & 5 & 4 & 5 & 4 & 5 & 4 & 36 & 4.50 \\
\hline S18 & 4 & 4 & 3 & 3 & 3 & 3 & 3 & 3 & 26 & 3.25 \\
\hline S19 & 2 & 2 & 2 & 2 & 2 & 3 & 1 & 1 & 15 & 1.87 \\
\hline S20 & 5 & 5 & 5 & 5 & 5 & 5 & 5 & 4 & 39 & 4.87 \\
\hline S21 & 2 & 3 & 2 & 2 & 2 & 2 & 3 & 3 & 19 & 2.37 \\
\hline S22 & 4 & 4 & 4 & 4 & 3 & 3 & 4 & 4 & 30 & 3.75 \\
\hline S23 & 3 & 4 & 4 & 4 & 4 & 3 & 4 & 4 & 30 & 3.75 \\
\hline S24 & 3 & 4 & 4 & 2 & 4 & 2 & 4 & 4 & 27 & 3.37 \\
\hline S25 & 4 & 4 & 4 & 4 & 4 & 4 & 4 & 4 & 32 & 4.00 \\
\hline S26 & 3 & 3 & 3 & 3 & 3 & 3 & 1 & 3 & 22 & 2.75 \\
\hline S27 & 4 & 4 & 4 & 4 & 4 & 4 & 4 & 4 & 32 & 4.00 \\
\hline \multicolumn{9}{|c|}{ Total } & \multicolumn{2}{|c|}{791} \\
\hline \multicolumn{9}{|c|}{ Mean } & \multicolumn{2}{|c|}{3.66} \\
\hline \multicolumn{9}{|c|}{ Standard Deviation } & \multicolumn{2}{|c|}{5.28} \\
\hline
\end{tabular}

Based on the table above, it can be seen the students' knowledge in learning English through blended learning at English Education Department in Universitas Lancang Kuning. The students' knowledge in learning English through blended learning at English Education Department in Universitas Lancang Kuning can be categorized into High. Based on table 4 above, the table showed that the total of raw score of students was 791 with the 
mean was 3.67 and the standard deviation of the students' score was 5.28 .

Table 5. Descriptive Statistic Scores the SubIndicators of Students Knowledge (Activities)

\begin{tabular}{|c|c|c|c|c|c|c|}
\hline \multirow{2}{*}{ NO } & \multicolumn{4}{|c|}{ Item } & \multirow{2}{*}{ Total } & \multirow{2}{*}{ Mean } \\
\hline & 1 & 2 & 3 & 4 & & \\
\hline $\mathrm{S} 1$ & 3 & 3 & 3 & 3 & 12 & 3.00 \\
\hline $\mathrm{S} 2$ & 3 & 4 & 5 & 4 & 16 & 4.00 \\
\hline S3 & 3 & 5 & 5 & 5 & 18 & 4.50 \\
\hline S4 & 4 & 4 & 4 & 4 & 16 & 4.00 \\
\hline S5 & 4 & 5 & 5 & 4 & 18 & 4.50 \\
\hline S6 & 4 & 4 & 4 & 4 & 16 & 4.00 \\
\hline S7 & 3 & 4 & 4 & 4 & 15 & 3.75 \\
\hline S8 & 4 & 4 & 4 & 4 & 16 & 4.00 \\
\hline S9 & 4 & 4 & 4 & 4 & 16 & 4.00 \\
\hline $\mathrm{S} 10$ & 4 & 4 & 4 & 4 & 16 & 4.00 \\
\hline S11 & 3 & 3 & 4 & 3 & 13 & 3.25 \\
\hline $\mathrm{S} 12$ & 4 & 4 & 4 & 4 & 16 & 4.00 \\
\hline S13 & 2 & 2 & 4 & 2 & 10 & 2.50 \\
\hline S14 & 4 & 4 & 4 & 4 & 16 & 4.00 \\
\hline $\mathrm{S} 15$ & 3 & 3 & 4 & 4 & 14 & 3.50 \\
\hline S16 & 3 & 3 & 3 & 3 & 12 & 3.00 \\
\hline S17 & 5 & 4 & 5 & 4 & 18 & 4.50 \\
\hline $\mathrm{S} 18$ & 3 & 3 & 3 & 3 & 12 & 3.00 \\
\hline S19 & 2 & 3 & 1 & 1 & 7 & 1.75 \\
\hline S20 & 5 & 5 & 5 & 4 & 19 & 4.75 \\
\hline $\mathrm{S} 21$ & 2 & 2 & 3 & 3 & 10 & 2.50 \\
\hline S22 & 3 & 3 & 4 & 4 & 14 & 3.50 \\
\hline $\mathrm{S} 23$ & 4 & 3 & 4 & 4 & 15 & 3.75 \\
\hline $\mathrm{S} 24$ & 4 & 2 & 4 & 4 & 14 & 3.50 \\
\hline $\mathrm{S} 25$ & 4 & 4 & 4 & 4 & 16 & 4.00 \\
\hline S26 & 3 & 3 & 1 & 3 & 10 & 2.50 \\
\hline S27 & 4 & 4 & 4 & 4 & 16 & 4.00 \\
\hline \multicolumn{5}{|c|}{ Total } & \multicolumn{2}{|c|}{391} \\
\hline \multicolumn{5}{|c|}{ Mean } & \multicolumn{2}{|c|}{3.62} \\
\hline \multicolumn{5}{|c|}{ Standard Deviation } & \multicolumn{2}{|c|}{2.90} \\
\hline
\end{tabular}

Based on the table above, it can be seen the subindicators of knowledge was activities in learning English through blended learning at English Education Department in Universitas Lancang Kuning can be categorized into High. Based on table 5 above, the table showed that the total of raw score of students was 391 with the mean was 3.62 and the standard deviation of the students' score was 2.91.
Table 6. Descriptive Statistic Scores the SubIndicators of Students Knowledge (Progress)

\begin{tabular}{|c|c|c|c|c|c|c|}
\hline \multirow{2}{*}{ NO } & \multicolumn{7}{|c|}{ Item } & \multirow{2}{*}{ Total } & Mean \\
\cline { 2 - 6 } & $\mathbf{1}$ & $\mathbf{2}$ & $\mathbf{3}$ & $\mathbf{4}$ & & \\
\hline S1 & 4 & 4 & 3 & 4 & 15 & 3.75 \\
\hline S2 & 4 & 3 & 4 & 4 & 15 & 3.75 \\
\hline S3 & 4 & 4 & 3 & 3 & 14 & 3.50 \\
\hline S4 & 3 & 5 & 4 & 5 & 17 & 4.25 \\
\hline S5 & 4 & 4 & 5 & 5 & 18 & 4.50 \\
\hline S6 & 4 & 5 & 5 & 4 & 18 & 4.50 \\
\hline S7 & 3 & 2 & 2 & 4 & 11 & 2.75 \\
\hline S8 & 3 & 4 & 4 & 4 & 15 & 3.75 \\
\hline S9 & 4 & 4 & 4 & 4 & 16 & 4.00 \\
\hline S10 & 4 & 5 & 4 & 4 & 17 & 4.25 \\
\hline S11 & 4 & 4 & 3 & 3 & 14 & 3.50 \\
\hline S12 & 3 & 4 & 3 & 4 & 14 & 3.50 \\
\hline S13 & 4 & 4 & 4 & 3 & 15 & 3.75 \\
\hline S14 & 4 & 4 & 4 & 4 & 16 & 4.00 \\
\hline S15 & 4 & 5 & 4 & 3 & 16 & 4.00 \\
\hline S16 & 3 & 3 & 3 & 3 & 12 & 3.00 \\
\hline S17 & 5 & 4 & 5 & 4 & 18 & 4.50 \\
\hline S18 & 4 & 4 & 3 & 3 & 14 & 3.50 \\
\hline S19 & 2 & 2 & 2 & 2 & 8 & 2.00 \\
\hline S20 & 5 & 5 & 5 & 5 & 20 & 5.00 \\
\hline S21 & 2 & 3 & 2 & 2 & 9 & 2.25 \\
\hline S22 & 4 & 4 & 4 & 4 & 16 & 4.00 \\
\hline S23 & 3 & 4 & 4 & 4 & 15 & 3.75 \\
\hline S24 & 3 & 4 & 4 & 2 & 13 & 3.25 \\
\hline S25 & 4 & 4 & 4 & 4 & 16 & 4.00 \\
\hline S26 & 3 & 3 & 3 & 3 & 12 & 3.00 \\
\hline S27 & 4 & 4 & 4 & 4 & 16 & 4.00 \\
\hline & & Total & & & $\mathbf{4 0 0}$ \\
\hline & & & & & $\mathbf{3}$ \\
\hline
\end{tabular}

Based on the table above, it can be seen the subindicators of knowledge was progress in learning English through blended learning at English Education Department in Universitas Lancang Kuning can be categorized into High. Based on table 6 above, the table showed that the total of raw score of students was 400 with the mean was 3.70 and the standard deviation of the students' score was 2.72 . 
Based on the table above, the researcher concluded the mean of interest was 3.71 can be categorized into high. Then, the mean of knowledge was 3.67 also can be categorized into high. Standard deviation of interest was 6.83 and for knowledge was 5.2. The data from the questionnaires were compiled and analyzed for common themes and patterns. To get a sense of the attitudinal nature of the comments, the data were classified as positive, negative, or neutral. Some participants had comments that had both positive and negative components so these were counted separately and classified accordingly. The positive comments came from strongly agree and agree, while negative comments came from disagree and strongly disagree. Referring to the presentation and analysis of the research data above, the result of found out the exploring students' interest and knowledge in blended learning context of English Education Department in Universitas Lancang Kuning was categories into High. That was shown from mean and standard deviation of students' score. This research had 2 problems that need to overcome:

\section{1) The students' interest in learn English through blended learning}

In this study, the researcher found 3 subindicators in learns English with blended learning. 3 sub-indicators consist of:

a) Motivation: Motivation as inspiring interest, persistence, attention, action, and enjoyment. (Smit, de Brabander, Boekaerts, \& Martens, 2017). Based on the results of the study, the motivation of students' interest in learn English through blended learning can be categorized into high. Because blended learning could increase the interest of the students in learning English remotely and without active supervision from the teacher (Hamuddin, Syahdan, Rahman, Rianita, \& Derin, 2019). Then, blended learning helped students' to carry out their academic tasks more efficiently, and the context were more motivating to learners than conventional ones.

b) Emotion: Emotions are intimately involved in virtually every aspect of the teaching and learning processes, therefore, an understanding of the nature of emotions within the school context is essential (Morris \& King, 2020). Based on the results of the study, sees the emotion of students' interest in learn English through blended learning can be categorized into high. Because blended learning helped the students' could repeat the materials at home or anywhere, the students preferred attending virtual class meetings more than attending face-to-face meetings, also the service that the faculty provided in blended learning context was good enough.

c) Interaction: interaction is reciprocal events that require at least two objects and two actions. Interactions occur when these 17 objects and events mutually influence one another (Doolan \& Gilbert,
2017). Based on the results of the study, the interaction of students' interest in learning English through blended learning can be categorized into high. This is because most of the students always gets in touch with familiar technology in their leaning process which helps them in getting information. Moreover, blended learning also offers the possibilities to efficiently manage their time as it forces both students and teachers to self-manage their time in speaking through screens within a limited time frame (Yuzar, 2020).

\section{2) The students' familiarity using blended learning}

In this study, this study found 2 sub-indicators in learns English with blended learning. 2 subindicators consist of:

a) Activities: activities are defined as 'any activities of an individual organized with the intention to improve his/her knowledge, skills and competences' (European Commission, 2006). Based on the results of the study, the activities of students' familiarity using blended learning can be categorized into high. Because, they were satisfied through using blended learning, and the students felt the blended learning is suitable for them, also they were more enjoying in learn English.

b) Progress: Progress is the process of gradually improving or getting nearer to achieving or completing something (Oxford Advanced Learner's Dictionary, 2013). The progress of a situation or action is the way in which it develops. Based on the results of the study, the progress of students' familiarity using blended learning can be categorized into high. Because, using blended learning helped them to learn and increase their knowledge and gave their facilitate to meet those learning goals.

From the results of research that has been done, the interest and knowledge of students in learning English using blended learning at English Education Department in Universitas Lancang Kuning can be categorized into high. Refers to the previous research from Ja'ashan (2015). "Perceptions and Attitudes towards Blended Learning for English Courses: A Case Study of Students at University of Bisha." The results conducted a survey through a questionnaire at University of Bisha, English department from eight levels of undergraduate program in both boys and girls colleges.

This study also concluded that blended learning is as effective as face to face learning in developing and improving knowledge and skills. Then, refers to the previous research by Eryilmaz (2015). "The Effectiveness of Blended Learning Environments." Further, mentioned that. "The study was applied to 110 students who attend to Atilim University, Ankara, Turkey and take Introduction to Computers Course and the results of the analysis, showed a significant difference between students' view in relation with 
blended learning environment as well as online and face to face learning environments. In their answers, students have expressed that they learned more effectively in a blended learning environment.".

Therefore, referring to the presentation and analysis of the research data above, the finding of the whole participants (27 students) led the researcher to infer that the students' interest and knowledge in blended learning context at English Education Department in Universitas Lancang Kuning into high categorized. Referring to the aims of survey design research, the findings of this research have purpose to give information for the all students', readers and lecturer about the students' interest and knowledge of students in learning English using blended learning at English Education Department in Universitas Lancang Kuning. The sub-indicators of interest such as, motivation, emotion and interaction and then the sub indicators of knowledge such as, activities and progress. The findings of this research are hopefully to increase the students' interest and knowledge in learning English using blended learning at English Education Department in Universitas Lancang Kuning.

\section{Conclusion}

The purpose of this research is to find out the students' interest and knowledge in learning English through blended learning context at English Education Department in Universitas Lancang Kuning. In this study, the researchers found 3 sub indicators in learn English with blended learning. 3 sub indicators consist of: Motivation, Emotion and Interaction. The students' interest in learn English through blended learning from scoring measurement, there was result of mean 3.71 into High categorized and the standard deviation was 6,83. It means was students' interest in learn English with blended learning. So, the students have suggest positive about the use blended learning in learn English. In this study, the researchers found 2 sub indicators in learn English through blended learning. 2 sub indicators consist of: Activities and Progress. The students' knowledge using blended learning from scoring measurement, there was result of mean 3.67 into High categorized and the standard deviation was 5,28. So, the students have understanding about how to use blended learning in learn English.

\section{References}

Arikunto. (1996). Prosedur Penelitian Suatu Pendekatan Praktik. Edisi Revisi. Jakarta: Rineka Cipta.

Bailey, J., Martin, N., Schneider, C., Vander Ark, T., Duty, L., Ellis, S., ... \& Terman, A. (2013). Blended learning implementation guide 2.0. Digital Shift.
Bath, D., \& Bourke, J. (2010). Blended Learning. Griffith University.

Black, A., \& Muddiman, D. (2017). Understanding community librarianship: the public library in post-modern Britain. Routledge.

Bond, M., Buntins, K., Bedenlier, S., ZawackiRichter, O., \& Kerres, M. (2020). Mapping research in student engagement and educational technology in higher education: A systematic evidence map.International Journal of Educational Technology in Higher Education, 17(1), 1-30

Crane, G. (2016). A Digital Public Library of America and the Transformation of the Humanities. Tuft University. The Perseus Digital Library.

DeMillo, R. A., Ferri, B., Harris, J., Ferri, A., Joyner, D., Braunstein, M., ... \& Buchman, T. G. (2019). Blended Learning in Practice: A Guide for Practitioners and Researchers. MIT Press.

Doolan, M. A., \& Gilbert, T. (2017). Student choice: blends of technology beyond the university to support social interaction and social participation in learning. In E-Learning, EEducation, and Online Training (pp. 95-102). Springer, Cham.

Eryilmaz, M. (2015). The effectiveness of blended learning environments. Contemporary Issues in Education Research (CIER), 8(4), 251-256.

European Commission. (2006). Classification of Learning Activties - Manual. Luxembourg: Office for Official Publications of the European Communities.

Hamuddin, B., Syahdan, S., Rahman, F., Rianita, D., \& Derin, T. (2019). Do They Truly Intend to Harm Their Friends?: The Motives Beyond Cyberbullying among University Students. International Journal of Cyber Behavior, Psychology and Learning (IJCBPL), 9(4), 32-44.

Ja'ashan, M. M. N. H. (2015). Perceptions and Attitudes Towards Blended Learning for English Courses: A Case Study of Students at University of Bisha. English Language Teaching, 8(9), 4050 .

Junaidi, J., Hamuddin, B., Julita, K., Rahman, F., \& Derin, T. (2020). Artificial Intelligence in EFL Context: Rising Students' Speaking Performance with Lyra Virtual Assistance. International Journal of Advanced Science and Technology, 29(5), 6735-6741.

Kamelia, K. (2019). Using Video as Media of Teaching in English Language Classroom: Expressing Congratulation and Hopes. Utamax: 
Journal of Ultimate Research and Trends in Education, 1(1), 34-38.

Knoke, D., Marsden, P. V., \& Kalleberg, A. L. (2017). Survey research methods. The Blackwell companion to organizations, 781-804.

Medora, N., \& Roy, R. N. (2017). Recruiting, organizing, planning, and conducting a 3-week, short-term study abroad program for undergraduate students: Guidelines and suggestions for first-time faculty leaders. International Journal of Humanities and Social Science Research, 3, 1-11.

Morris, S., \& King, J. (2020). 11 Emotion Regulation among University EFL Teachers in Japan: The Dynamic Interplay between Context and Emotional Behaviour. The emotional rollercoaster of language teaching.

Nursafira, M. S. (2020). TED Talks in EFL Context: An Alternative Way for Teaching and Improving Student's Speaking Skills. ELSYA: Journal of English Language Studies, 2(2), 7-11.

Oxford Advanced Learner's Dictionary. (2013). Oxford University Press; 8 edition.

Putri, N. S. (2019). Kahoot Application in English Language Teaching (ELT) Context: An Alternative Learning Strategy. ELSYA: Journal of English Language Studies, 1(1), 11-15. https://doi.org/10.31849/elsya.v1i1.2488

Putri, S. E., Hamuddin, B., Nursafira, M. S., \& Derin, T. (2020). Discourse Analysis in E-LearningBased Course Using Moodle Platform: An Experimental Design. REiLA: Journal of Research and Innovation in Language, 2(1).

Sağin, F. G. (2020). How to use educational technology to make education better-Not just different or entertaining!. Biologia Serbica, 41(2).

Smit, K., de Brabander, C. J., Boekaerts, M., \& Martens, R. L. (2017). The self-regulation of motivation: Motivational strategies as mediator between motivational beliefs and engagement for learning. International Journal of Educational Research, 82, 124-134.

Story, D. A., \& Tait, A. R. (2019). Survey research. Anesthesiology: The Journal of the American Society of Anesthesiologists, 130(2), 192-202.

Strogilos, V., Stefanidis, A., \& Tragoulia, E. (2016). Co-teachers' attitudes towards planning and instructional activities for students with disabilities. European Journal of Special Needs Education, 31(3), 344-359.
Yudar, R. S., Aditomo, D. T., \& Silalahi, N. S. (2020). Movie as a Helper for Students' Pronunciation in Speaking Skill Class. ELSYA: Journal of English Language Studies, 2(1). 15-19.

Yuzar, E. (2020). Incorporating Communicative Competence in Assessment and English Language Teaching in Multilingual Settings. REiLA: Journal of Research and Innovation in Language, 2(1). 8-13. 